\title{
Reducing surgical site infections (SSI) in breast surgeries, including a newly identified risk for sentinel node biopsies
}

\author{
M Catlin", C Blue, R Thompson, A Nelson \\ From 3rd International Conference on Prevention and Infection Control (ICPIC 2015) \\ Geneva, Switzerland. 16-19 June 2015
}

\section{Introduction}

In 2012, 19 infections out of 561 breast surgeries (Standardized infection Ratio (SIR) 3.372, 95\% CI 2.09-5.168) led to the discovery that non-sterile radiation probes pierced their sterile sheaths. After disinfecting the probes, the SSI was $0 \%$, then subsequently increased.

\section{Objectives}

The objective of this study was to identify risk factors for continued infections in 2013 and 2014.

\section{Methods}

Rates of SSI were calculated for each surgeon. Case control analyses identified risk factors using $\mathrm{R}$ version 3.1.2. Cases were observed and results shared with surgical teams.

\section{Results}

Of 26 surgeons, Surgeon X had 33\% (386) of the 1169 procedures in $2012-2013$ and $52 \%(13 / 25)$ of the infections: the SSI rate was $3.38 \%(13 / 384)$, which was significantly greater than expected 0.32 from the U.S. National Health Safety Network risk adjusted control cases (SIR 3.117 ( 95\% CI1.73-5.20)).

Surgeon X's sentinel node biopsies in 2014 had a 9-fold increased SSI risk (OR 9.0, Fisher Exact, $\mathrm{p}=.051$ ); several practice variations were observed.

\section{Conclusion}

The rate of SSI was reduced to zero in the $4^{\text {th }}$ QTR of 2014, after communicating surgeon-specific rates, possible risk factors, and peer coaching. Practice changes

Infection Prevention and Employee Health, Group Health Cooperative, Seattle, WA, USA included high-level disinfection (HLD) of radiation probes used in surgical fields, use of disposable hair bonnets, anchoring drains, and revised prepping.

\section{Disclosure of interest}

None declared.

Published: 16 June 2015

doi:10.1186/2047-2994-4-S1-031

Cite this article as: Catlin et al:: Reducing surgical site infections (SSI) in breast surgeries, including a newly identified risk for sentinel node biopsies. Antimicrobial Resistance and Infection Control 2015 4(Suppl 1):031.
Submit your next manuscript to BioMed Central and take full advantage of:

- Convenient online submission

- Thorough peer review

- No space constraints or color figure charges

- Immediate publication on acceptance

- Inclusion in PubMed, CAS, Scopus and Google Scholar

- Research which is freely available for redistribution

Submit your manuscript at www.biomedcentral.com/submit
() Biomed Central 